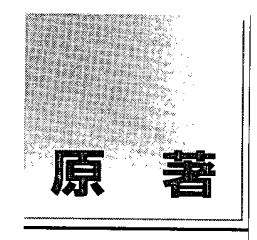 \\ 2002年1 $\begin{array}{r}\text { 論文受付 } \\ \text { 月28 } \\ \text { 椧女受理 }\end{array}$

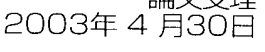 \\ Code Nos. 820 \\ 緒 言 \\ マンモグラフィにおける乳癌の検出率が，被検者の

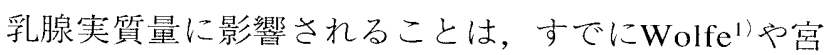 城ら ${ }^{2)}$ によて指摘されており, マンモグラフィガイ ドライン3でも，乳腺実質の量と分布を，病変が正常 乳腺に隠される危険性の程度として評価している。さ らに, Sobol ${ }^{4)}$ は平均乳腺線量の算出過程に扮いて, 乳 腺含有率を必要な变数として挙げている。これらの指 摘は, 病変検出能や被曝線量の評価において, 乳腺含
}

\section{乳腺含有率の推定打よび推定值に対する年齢階級と 压迫乳房厚の統計的影響関係の分析}

\author{
大森直樹·芦田健次 ·藤田 修
}

大阪医科大学附属病院放射線科

有率が考慮すべき重要な因子であることを示唆してい る.したがって, 乳腺含有率の実態を把握すること は, マンモグラフィ研究において重要な意義を有する と考えられる。Wolfe $\mathrm{e}^{5)}$ は, マンモグラフィに扮ける 乳腺実質量の視覚的分類と発癌リスクとの関係を検討 した研究のなかで，乳腺実質量が加齢とともに減少す る傾向にあることを指摘している。またGeiseら6)は， 乳腺含有率と乳房撮影時の圧迫乳房厚 (compressed breast thickness：以下，CBT) との統計的な関係から，

\section{Estimation of Glandular Content Rate and Statistical Analysis of the Influence of Age Group and Compressed Breast Thickness on the Estimated Value}

\author{
NAOKI OHMORI, KENJI ASHIDA, and OSAMU FUJITA \\ Department of Radiology, Osaka Medical College Hospital \\ Received Nov. 28, 2002; Revision accepted April 30, 2003; Code Nos. 820,862
}

\section{Summary}

Because the glandular content rate is an important factor in evaluating breast cancer detection and average glandular dose, it is important in mammography research to estimate and analyze this rate. The purpose of this study was to obtain a formula for statistical estimation of the glandular content rate, to clarify statistically the influence of age group and compressed breast thickness (CBT) on estimating the glandular content rate, and to show statistically the general relation between glandular content rate and the factors of age and CBT. The subjects were 740 Japanese women aged 20-91 years (mean \pm SD: $48.3 \pm 12.8$ years) who had undergone mammography. In our study, the glandular content rate was statistically estimated from age group, $m A s-v a l u e$, and CBT when subjects underwent mammography, from a phantom simulation, and from MR images of the breast. In addition, multivariate analysis was carried to examine statistically the influence of age group and CBT on glandular content rate. The mean glandular content rate as estimated by age group was as follows: $35.6 \%$ for those in their $20 \mathrm{~s}, 33.4 \%$ in the $30 \mathrm{~s}, 27.5 \%$ in the $40 \mathrm{~s}, 23.8 \%$ in the $50 \mathrm{~s}$, and $21.8 \%$ in those 60 and over. The rate for the subjects as a whole was $27.1 \%$. This study indicated that overestimation occurred if the estimated value of the glandular content rate was not corrected in the 3D-measurement by MRI. In addition, this study showed that the statistical influence on glandular content rate was significantly larger for CBT than age.

Key words: Mammography, Glandular content rate, Age group, Compressed breast thickness,

Magnetic resonance imaging (MRI)

別刷資料請求先：テ569-8686 高梘市大学町 2-7

大阪医科大学附属病院放射線科 大森直樹 宛 
負の相関性が認められることを示している。しかし， 乳腺含有率在作秢要因とCBT装因加推定し，乳腺含 有桬と雨慗因との間にどのような影響関係が認められ るのかを，統計的に分析した報告はほとんどみられ ず，刨括的な理解を困難にしている現状がある。そこ で本研究では，刘泉洋の年齢階級と乳房撮影条件，扔 よび自作ファントムによるシミュレーション実験と対 象群の一部に実施された乳腺MRI (magnetic resonance imaging)の画像より，脌齢階級とCBTを要因として, 統計的に乳㟫含有率を推定する関係式を求めた。さら に多変量解析によって，乳腺含有乷に対する年齢階級 とCBTとの影響関係を分析し考察したので報告する。

\section{1. 対 象}

1997年12月から1998年11月までに，当院で乳房撮 影を受けた被検者のうち, 撮影時の管電圧, ターゲッ ト，フィルタの組み合わせが同一であった740症例(20 ～91歳，平均年齢：48.3土12.8歳）を対象とした。男 性，授乳期女性，㧍よびホルモン療法中の患者は対象 に含めず，分析は頭尾方向撮影に限定した。

\section{2. 方 法}

\section{2-1 対象への乳房撮影}

乳房撮影装置はSenographe DMR (GE横河メデイカ ルシステム株式会社製)が使用された。自動露出制御 (automatic exposure control：以下, AEC)は, 管電 圧，ターゲット，フィルタの自動選択が可能な 3 種類 のAOP (automatic optimization of parameter) モードフ のうち、コントラストを優先するアルゴリズムを選択

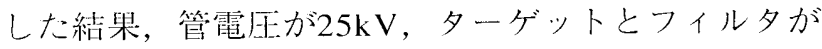
いずれもモリブデンとなった怔例を対象とした(全体 の92\%)。たたし，乳房压迫圧は100Nで撮影された。

\section{2-2 各年齢階級におけるCBTとmAs值間の統計的関 係の推定}

対象の年齢階級別に, CBT と管電流時間積值（以 下, mAs值) との関係を，多項式による非線形回帰分 析で推定した。対象の年齢階級は，20歳代，30歳代， 40歳代，50歳代，60歳以上の5階級に分類した。本研 究では, $\mathrm{mAs}$ 值に対する変数操作を行い,「 $\mathrm{mAs}$ 值の 対数をCBTで除した値」在從属变数として扱った。非 線形回帰分析は，多項式の次数を2〜7次まで1次ず つ增やして分析した。この結果から，最も合理的な回 帰精度を与える多項式の次数を決定し，年齢階級别に 回帰式を求めた。多項式の次数に対する妥当性は, 決 定係数により評侀した。たたし，決定係数は，各华齢 階級に㧈ける標本数の相違を考慮して, 自目度調整済 み決定係数 (以下, $\mathrm{R}^{* 2}$ ) とした。
2-3 ファントムによるシミュレーション実験

Senographe DMRに拈ける, 乳房撮影条件 (CBT, $\mathrm{mAs}$ 值) と乳腺含有卒との関係式を得るため, 自作の water/fatファントム存使用してシミュレーション撮影 を行った。

シミュレーションに使用したwater/fatファントム

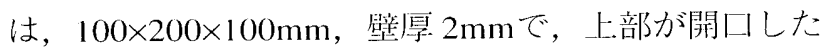
アクリル製容器に, 生理食填水 $\left(\rho=1.006 \mathrm{~g} / \mathrm{ml}\right.$ at $\left.20^{\circ} \mathrm{C}\right)$ および純度 $100 \%$ コーンオイル $\left(\rho=0.96 \mathrm{~g} / \mathrm{ml}\right.$ at $\left.20^{\circ} \mathrm{C}\right)$ を注入した後，自然分離するまで放䈯し，2層化した ものである。アクリル容器底䤄の壁厚 $2 \mathrm{~mm}$ は, 近似 的にX線の入射方向に対与る前後の皮膚層 $($ 各 $1 \mathrm{~mm}) に$ 刘芯していると仮定した。また，今回のシミュレーシ ヨンでは，Stanton"およびSato"のう法に従い，皮霄 曆と皮下脂肪層の合計を $5 \mathrm{~mm}$ として定数化した。こ の場合，度下脂肪層は $4 \mathrm{~mm}$ となるため，前後の支下 脂肪層を考慮し， 2 倍の $8 \mathrm{~mm}$ 厚のコーンオイル層を皮 下脂肪層として付加した(Fig. 1)。以上より，CBTに 相当するファントム厚 (phantom thickness：以下，PT) は(1)式に示すように，コーンオイル層: $d_{1}(\mathrm{~mm})$, 生 理食塩水層： $d_{2}(\mathrm{~mm})$ ，拈よび皮下脂肪層： $8 \mathrm{~mm}$ とア クリル容器の壁厚： $2 \mathrm{~mm}$ を合計した厚さとなる。

$$
P T=\left(d_{1}+d_{2}\right)+10
$$

皮下脂肪廨に相当する $8 \mathrm{~mm}$ 厚のコーンオイル層を 除いた，生理食塩水とコーンオイルの全注入量に対す 万生理食塩水の比率を, 模擬的乳腺含有率 [ simulated glandular content rate：以下, $\operatorname{SGC}(\%)] と し て$ 定義し な。ここで，生理食㗕水層とコーンオイル層の底面積 は同一かつ一等であるので， $\operatorname{SGC}(\%)$ は(2)式に赤す ように，两層の厚さの和に対する生理食塭水層の厚さ の百分率として求めた。

$$
S G C(\%)=\left\{d_{2} /\left(d_{1}+d_{2}\right)\right\} \cdot 100
$$

ファントム厚 $\mathrm{P} \mathrm{PT}=10,20,30,40,50,60 \mathrm{~mm}$ に 対して，それぞれSGC（\%)を $0 \%$ から $100 \%$ ま゙10\% ずつ変化させてシミュレーション撮影を行い, 各 $\mathrm{mAs}$ 值を測定した。mAs值の測定結果をもとに，PTと $\mathrm{SGC}(\%)$ との関係式を線形回帰分析によって求めた。 管電压，ターゲット，フィルタは対象群の撮影と同一 とし, 昉さ $2 \mathrm{~mm}$ のポリカーボネイト製の圧迫板も付

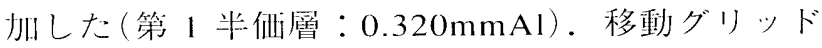
$(31 \mathrm{lp} / \mathrm{cm}, 5: 1)$ を内蔵したカセッテホルダには，䧗 㕅で使用しているカセッテにフィルムを入れて装填し た。使用したフィルム，スクリーン，カセッテは，そ れぞれUM-MA HC, UM MAMMOFine, EC-MA(富 


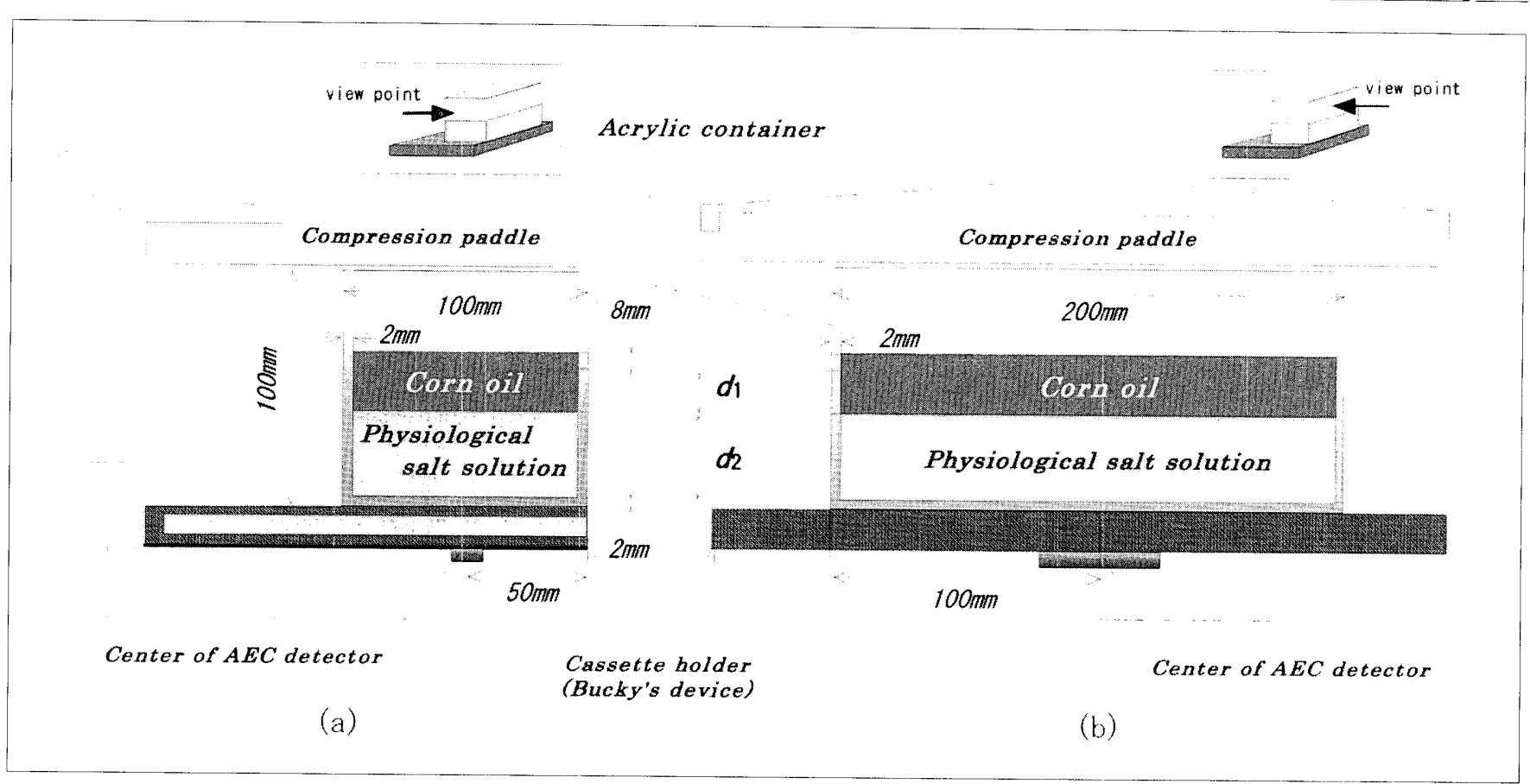

Fig. 1 Geometrical relation between simulation phantom and mammography device.
(a) Lateral view of arrangement plan.
(b) Front view of arrangement plan.

士メディカルシステム株式会社製)である、AEC受光 部の中心は, water/fatファントムの中央となる胸壁側 から $5 \mathrm{~cm}$ の位蹎とし，AECの濃度設定は，対象群の撮 影時と同一とした。シミュレーション撮影によるmAs 值の測定は，連続で 3 回ずつ行ったが，表示された mAs值はすべて同值であり，シミュレーション撮影全 般を通じて $\mathrm{mAs}$ 值の変動は無視できた。

\section{2-4 MRIによる乳腺含有率測定}

対象群のうち，乳腺のMRI検査も受けた被検者のな かから，2cm超える腫瘤径の乳房を除いた57症例に 刘し，撮影されていたT强調横断像からボリュームレ ンダリング法による三次元画像を再棈成した。この三 次元画像から乳頭，皮下脂肪，胸筋，腫瘤を除き，脂 肪組織と乳腺組織の体積を測定した。雨組織の体積和 に対する乳腺組織の体積比（\%)を算出し，これを乳腺 含有率として評洒した。三次元画像の再椿成拉よび体 積測定は，Advantage Windows 2.0 (GE社製)によって 行った。MR装䈯はSIGNA Horizon 1.5T(GE社製)， コイルは乳房専用コイル, パルスシーケンスはspin echo, 撮像パラメータはTR=600 $\mathrm{msec}, \mathrm{TE}=14 \mathrm{msec}$, band width $= \pm 16 \mathrm{kHz}, \mathrm{NEX}=1$, matrix $=256 \times 160$, $\mathrm{FOV}=16 \times 16 \mathrm{~cm}$, thickness $=6 \mathrm{~mm}$, gap=0 $\mathrm{mm}$ であっ た。

\section{3. 結 罪}

\section{3-1 各年齢階級におけるCBTとmAs值間の統計的関 係の推定}

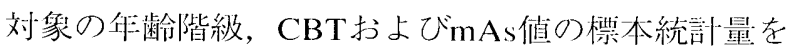
Table 1に示す。CBTとmAs值との関係に扮ける非線非 性を確譛するため，金刘集に抢ける回帰分析を行。 た。その結果，従属变数が $\mathrm{mAs}$ 值の場合は $R^{* 2}=.625$ で あったが，従属变数を $\mathrm{mAs}$ 值の対数：In $(m A s)$ とした 場合では $R^{* 2}=.754$ となり，回帰精度の问上が垫められ た。これより，CBTとmAs值との関係は，線形関係よ りも非線形的な指数関数に近いことを確認した。

次に，非線形回帰分析における多項式の次数老決定 するため，多項式の次数を 2 7 次まで1 次ずつ分析 し，それぞれのR"2を比較した。分析対異は全年齢階 級とし，良属变数は $\ln (m A s)$ をCBTで除した值：[ In $(m A s) / C B T]$ とした。ただし独立変数は，CBTである 場合とその対数：In $(C B T)$ である場合を比較すること で，独立変数にも対数变換の必装性があるかを同時に 確認した。その結果，それぞれの独立変数に対する多 頁式の次数と $\mathrm{R}^{* 2}$ との関係は, $\mathrm{CBT}$ 場合, 2 次： $.877,3$ 次: .919, 4 次: .933, 5 次:.939, 6 次： .943, 7 次：.944であり, $\ln (C B T)$ の埸合は, 2 次： $.941,3$ 次: .945, 4 次: 945, 5 次: .945, 6 次：

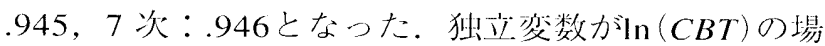
合，すべての次数が $R^{* 2}>940$ となったが，CBTの埸合 は, 次数が 6 次以上で $R^{* 2}>.940$ となった。よって, 独 
Table 1 Sample statistics for each of the age groups.

\begin{tabular}{|c|c|c|c|c|c|c|c|}
\hline \multicolumn{2}{|c|}{ Age group } & $20 \mathrm{~s}$ & $30 \mathrm{~s}$ & $40 \mathrm{~s}$ & $50 \mathrm{~s}$ & $60 y \leqq$ & whole \\
\hline \multicolumn{2}{|c|}{ Number of subjects } & 58 & 128 & 222 & 194 & 138 & 740 \\
\hline \multirow{2}{*}{$\operatorname{Age}(y)$} & Mean & 25.3 & 34.6 & 45.5 & 53.6 & 67.3 & 48.3 \\
\hline & $\mathrm{SD}$ & 2.9 & 3.0 & 2.6 & 2.5 & 6.0 & 12.8 \\
\hline \multirow{2}{*}{$\begin{array}{l}\text { Compressed } \\
\text { breast } \\
\text { thickness }(\mathrm{mm})\end{array}$} & Mean & 27.9 & 27.5 & 31.2 & 34.6 & 31.8 & 31.4 \\
\hline & SD & 9.0 & 9.9 & 10.7 & 10.9 & 10.8 & 10.8 \\
\hline \multirow{2}{*}{ mAs-value } & Mean & 101.6 & 81.3 & 90.2 & 86.6 & 63.8 & 84.2 \\
\hline & $\mathrm{SD}$ & 58.4 & 52.9 & 57.1 & 50.2 & 36.0 & 52.3 \\
\hline
\end{tabular}

Table 2 Formulas relating $\ln (m A s) / C B T$ and $\ln (C B T)$ to each of the age groups. $\mathrm{Y}$ and $\mathrm{X}$ within the formulas symbolize $\ln (m A s) / C B T$ and $\ln (C B T)$, respectively.

\begin{tabular}{ccc}
\hline Age group & Third degree polynomial regression formula & Adjusted R-square \\
\hline $20 \mathrm{~s}$ & $\mathrm{Y}=1.870-1.263 \mathrm{X}+0.3248 \mathrm{X}^{2}-0.02988 \mathrm{X}^{3}$ & .974 \\
$30 \mathrm{~s}$ & $\mathrm{Y}=1.773-1.219 \mathrm{X}+0.3207 \mathrm{X}^{2}-0.03019 \mathrm{X}^{3}$ & .973 \\
$40 \mathrm{~s}$ & $\mathrm{Y}=1.199-0.642 \mathrm{X}+0.1296 \mathrm{X}^{2}-0.00945 \mathrm{X}^{3}$ & .939 \\
$50 \mathrm{~s}$ & $\mathrm{Y}=1.265-0.715 \mathrm{X}+0.1537 \mathrm{X}^{2}-0.01200 \mathrm{X}^{3}$ & .953 \\
$60 \mathrm{y} \leqq$ & $\mathrm{Y}=1.386-0.858 \mathrm{X}+0.2017 \mathrm{X}^{2}-0.01705 \mathrm{X}^{3}$ & .980 \\
whole & $\mathrm{Y}=1.377-0.821 \mathrm{X}+0.1883 \mathrm{X}^{2}-0.01580 \mathrm{X}^{3}$ & .944 \\
\hline
\end{tabular}

Table 3 Formulas relating SGC (\%) and $\ln (m A s) / P T$ to each PT. Y and $X$ within the formulas symbolize $S G C(\%)$ and $\ln (m A s) / P T$, respectively.

\begin{tabular}{ccc}
\hline \hline Phantom thickness $(\mathrm{mm})$ & Linear regression formula & R-square \\
\hline 10 & $Y=1422.1 \mathrm{X}-280.83$ & .993 \\
20 & $\mathrm{Y}=1709.4 \mathrm{X}-216.67$ & .995 \\
30 & $\mathrm{Y}=1816.9 \mathrm{X}-186.36$ & .996 \\
40 & $\mathrm{Y}=1896.9 \mathrm{X}-172.24$ & .997 \\
50 & $\mathrm{Y}=1940.3 \mathrm{X}-162.38$ & .995 \\
60 & $\mathrm{Y}=1958.8 \mathrm{X}-154.60$ & .994 \\
\hline
\end{tabular}

立変数は $\ln (C B T)$ とする方が妥当であった．独立変数 が $\ln (C B T)$ の場合，3次以上の次数では $\mathrm{R}^{* 2} に$ 明らかな 相違を認めなかった。よって，回帰式の繁雑性を考慮 すると，多項式は3 次式とすることが妥当であった. この場合の $R^{* 2}=.944$ は，変数操作をする前の $R^{* 2}=.754$ を大きく上回っていた，以上より，独立変数をln $(C B T)$, 従属変数を $[\ln (m A s) / C B T]$ と寸る, 3 次多項 式に上る非線形回帰分析から，各年齢階級における CBTとmAs值との関係式を求めた (Table 2).

3-2 ファントムシミュレーション実験

ファントムシミュレーションから求められた $[\mathrm{ln}$ $(m A s) / P T]$ を独立変数とし, $\mathrm{SGC}(\%)$ を従属変数とし
た線形回㷌分析を10〜60mmのPTごとに行い，得られ た回帰式を而変数間の関係式とした (Table 3)。ただ し, 回帰直線の決定係数は, すべて.990以上であっ た.

次に, $P T=C B T$ と仮定し, Table 2 と Table 3の関係式 から，年齢階級別にCBT と $\mathrm{SGC}(\%)$ 関係式を求め た。まず， CBTと mAs值との関係を示す一般式は Table 2より(3) 式となる.

$$
\mathrm{Y}_{i}=b_{i}-a_{1 i} \mathrm{X}+a_{2 i} \mathrm{X}^{2}-a_{3 i} \mathrm{X}^{3}
$$

ただし， $\mathrm{X}=\ln (C B T), \quad \mathrm{Y}_{i}=[\ln (m A s) / C B T], \quad$ age group : $i=20 \mathrm{~s}, 30 \mathrm{~s}, 40 \mathrm{~s}, 50 \mathrm{~s}, 60 \mathrm{y} \leqq\}, \mathrm{b}_{i}$ と $\mathrm{a}_{1 i}, \mathrm{a}_{2 i}, \mathrm{a}_{3 i}$ 
は，それぞれ回帰定数と回帰係数である.PTとSGC （\%)との関係を示す一般式はTable 3より(4) 式とな る.

$$
S G C_{j}(\%)=-c_{j}+d_{j} Y_{j}
$$

ただし $, \mathrm{Y}_{j}=[\ln (m A s) / P T], \quad\{P T(\mathrm{~mm}): j=10,20,30$, $40,50,60\},-\mathrm{c}_{j}$ と $\mathrm{d}_{j}$ はそれぞれ回帰定数と回帰係数で ある。ここで，PT=CBTであると仮定すると，(3)式 は(5)式となり，(4)式は(6)式となる.

$$
\mathrm{Y}_{j}=\mathrm{Y}_{i j}=\left[b_{i}-a_{1 i} \mathrm{X}_{j}+a_{2 i} \mathrm{X}_{j}{ }^{2}-a_{3 i} \mathrm{X}_{j}^{3}\right]
$$

$S G C_{i j}(\%)=-c_{j}+d_{j} Y_{i j}$

$$
\text { ただし， } \mathrm{X}_{J}=\ln (P T)=\ln (C B T)
$$

さらに(5)式を(6)式に代入すると（7)式が得られる.

$$
S G C_{i j}(\%)=-c_{j}+d_{j}\left[b_{i}-a_{1 i} \mathrm{X}_{j}+a_{2 i} \mathrm{X}_{j}^{2}-a_{3 i} \mathrm{X}_{j}{ }^{3}\right]
$$

以上より，各年齢階級ごとにCBTを独立変数とする $\mathrm{SGC}(\%) の 一$ 般式が導出された。

この一般式から，年齢階級別にCBT $=10 ， 20 ， 30$, $40,50,60 \mathrm{~mm}$ SGC (\%)を算出し, その結果を 3 次 多項式近似することで，任意のCBTによってもSGC (\%)が計算可能となる近似式を求めた(Table 4).

\section{3-3 MRIによる乳腺含有率測定}

MRIによる乳腺含有率測定を行った57症例の年齢, および乳房撮影時のCBT とmAs值の平均值士標準偏差 は, 年齢 $(52.8 \pm 12.7$ 歳 $), \mathrm{CBT}(34.6 \pm 11.2 \mathrm{~mm}), \mathrm{mAs}$ 值 $(93.7 \pm 58.6)$ であった。また，測定された乳腺含有 率の平均值士標準偏差は，27.7土10.9\%であった。実 測された乳腺含有率を従属变数とし, Table 4の近似式 から求めた $\mathrm{SGC}(\%)$ を独立変数とした相関分析の結 果, 比較的高い正の相関性を示し $(r=.698$, $p<.0001$ ), 回帰式: $Y=0.267 X+7.669$ を得た (Fig. 2).

\section{3-4 対象群における乳腺含有率の推定および多変量 解析による検討}

Table 4の近似式とFig. 2の回帰式から, 対象群の乳 腺含有率を計算により求めた。計算の結果，各年齢階 級における乳腺含有率の平均值士標準偏差は，それぞ れ20歳代 (35.6 $57.0 \%) ， 30$ 歳代 $(33.4 \pm 6.0 \%) ， 40$ 歳代 $(27.5 \pm 6.4 \%), 50$ 歳代 $(23.8 \pm 6.0 \%), 60$ 歳以上 (21.8 $55.5 \%)$ となり，対象全体では $27.1 \pm 7.6 \%$ であっ た。年齢階級が高齢化するほど平均值は低值を示した ため，年齢要因の主効果を検定する目的で，一元配置

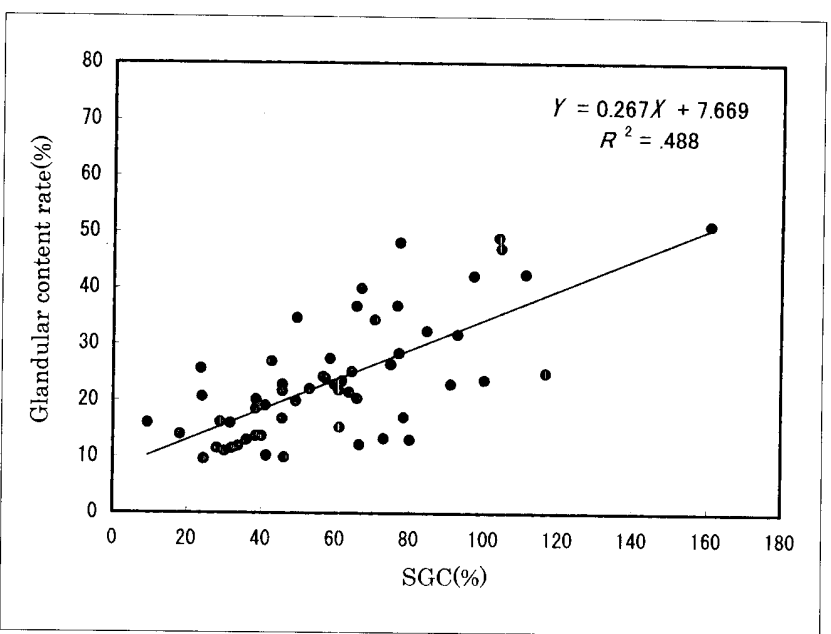

Fig. 2 Correlation between SGC (\%)and glandular content rate. Scatter diagram and regression formula show results of correlation analysis in 57 cases of MRI of the breast. Glandular content rates were obtained from volume measurement by MR. $R^{2}$ symbolizes the coefficient of determination (R-square).

分散分析を行った。ただし，Bartlett検定により，各年 齢階級の等分散性は $5 \%$ の危険率で認められている。 分析の結果, 年齢要因に有意な主効果が認められた $[F$ $(4,736)=103.55, p<.0001]$. 次に, 年齢階級間での 平均值の差の有意性を検定するため, 多重比較を行っ た．ただし，年龄階級間で標本数が異なるため，多重 比較はTukey-Kramer法10)を用いた，検定の結果，20 歳代と30歳代の間では有意差 $(p<.05)$ を認めなかった が，その他の年齢階級間では，すべての組み合わせで 有意差 $(p<.05)$ を認めた．以上より，少なくとも30歳 代以降では, 年齢階級の高齢化に伴う乳腺含有率の低 下傾向が示された。ささらに，乳腺含有率に対する年齢 要因とCBT要因の統計的な影響関係を評価するため, 年齢階級とCBTを独立变数とし，乳腺含有率を従属変 数とした，一括投入法による重回帰分析を行った。重 回帰式の有意性は分散分析により認められた $[F(2$, $738)=8609.2, p<.0001]$. 標準偏回㷌係数 $(\beta)$ は, 年 齢階級 $(\beta=-.448, p<.0001), \mathrm{CBT}(\beta=-.796$, $p<.0001)$ とも有意であり, 決定係数は $R^{2}=.959$ と独立 変数の高い説明率を示した。両要因の標準偏回帰係 数は，ともに負の值であったことから，両要因とも 乳腺含有率と負の相関関係にあることが支持され た.さらに，年齢階級と CBTの標準偏回帰係数を比 較すると，絶対值は年齢階級よりもCBTの方が有意 に大きかった。よって，乳腺含有率との統計的な関 係に対し，年齢要因よりもCBT要因の方が有意に影 響の大きいことを認めた。

2003 年 6 月 
Table 4 Estimated values of SGC (\%) and formulas relating SGC (\%) and CBT to each of the age groups. $Y$ and $X$ within formulas symbolize SGC (\%) and CBT, respectively.

\begin{tabular}{|c|c|c|c|c|c|c|c|}
\hline \multirow{3}{*}{ Age group } & \multicolumn{6}{|c|}{$\operatorname{SGC}(\%)$} & \multirow{3}{*}{ Third degree polynomial approximate formula } \\
\hline & \multicolumn{6}{|c|}{ Compressed breast thickness (mm) } & \\
\hline & 10 & 20 & 30 & 40 & 50 & 60 & \\
\hline $20 \mathrm{~s}$ & 173.0 & 121.7 & 97.0 & 76.0 & 52.9 & 27.2 & $Y=-1.5 \cdot 10^{-3} X^{3}+0.182 X^{2}-9.186 X+247.3$ \\
\hline $30 \mathrm{~s}$ & 145.1 & 108.7 & 90.7 & 72.3 & 49.8 & 23.7 & $Y=-1.1 \cdot 10^{-3} X^{3}+0.124 X^{2}-6.271 X+195.8$ \\
\hline $40 \mathrm{~s}$ & 134.8 & 98.6 & 72.4 & 54.3 & 40.4 & 29.0 & $Y=-0.5 \cdot 10^{-3} X^{3}+0.079 X^{2}-5.691 X+184.3$ \\
\hline $50 \mathrm{~s}$ & 127.2 & 90.4 & 65.8 & 48.4 & 34.3 & 22.0 & $Y=-0.6 \cdot 10^{-3} X^{3}+0.092 X^{2}-5.982 X+178.3$ \\
\hline $60 y \leqq$ & 106.7 & 71.6 & 52.8 & 39.0 & 26.3 & 13.6 & $Y=-0.9 \cdot 10^{-3} X^{3}+0.115 X^{2}-6.192 X+157.6$ \\
\hline
\end{tabular}

Table 5 Estimated values of glandular content rate and formulas relating glandular content rate and $C B T$ to each of the age groups. $Y$ and $X$ within formulas symbolize glandular content rate and $\mathrm{CBT}$, respectively.

\begin{tabular}{|c|c|c|c|c|c|c|c|}
\hline \multirow{3}{*}{ Age group } & \multicolumn{6}{|c|}{ Glandular content rate $(\%)$} & \multirow{3}{*}{ Third degree polynomial approximate formula } \\
\hline & \multicolumn{6}{|c|}{ Compressed breast thickness (mm) } & \\
\hline & 10 & 20 & 30 & 40 & 50 & 60 & \\
\hline $20 \mathrm{~s}$ & 53.6 & 41.0 & 33.2 & 28.0 & 23.0 & 15.8 & $Y=-3.92 \cdot 10^{-4} X^{3}+0.05 X^{2}-2.43 X+73.6$ \\
\hline $30 \mathrm{~s}$ & 46.2 & 37.4 & 31.5 & 27.0 & 21.9 & 14.4 & $Y=-2.97 \cdot 10^{-4} X^{3}+0.03 X^{2}-1.67 X+59.9$ \\
\hline $40 \mathrm{~s}$ & 43.7 & 33.8 & 26.7 & 21.6 & 17.6 & 14.2 & $Y=-1.24 \cdot 10^{-4} X^{3}+0.02 X^{2}-1.53 X+56.9$ \\
\hline $50 \mathrm{~s}$ & 41.6 & 32.0 & 25.4 & 20.8 & 17.4 & 14.2 & $Y=-1.61 \cdot 10^{-4} X^{3}+0.03 X^{2}-1.61 X+55.4$ \\
\hline $60 y \leqq$ & 36.1 & 27.2 & 21.8 & 18.4 & 15.7 & 12.3 & $Y=-2.30 \cdot 10^{-4} X^{3}+0.03 X^{2}-1.66 X+49.8$ \\
\hline
\end{tabular}

\section{3-5 乳腺含有率に対する年龄階級とCBTとの一般的} 関係

対集群における乳腺含有率の計算結果をもとに，年 齢階級別にCBTと乳腺禽有率との関係式を 3 次多項式 近似により求め，10，20，30，40，50，60mmのCBT に対応する年噛階級別の乳腺含有率を算出した（Table 5)。算出さ扎た乳腺含有率の最大值は，53.6\%(20歳 代， CBT $=10 \mathrm{~mm}$ )であり，最小值は $12.3 \%$ （60歳以上， $\mathrm{CBT}=60 \mathrm{~mm})$ であった。20歳代と60歳以上との乳腺含 有率を比較すると，CBTが10－50mmの場合，60歳以 上は20藏代に対して0.32 0.340比率であり，CBTに よらずほぼ一定であることを示した。また，50歳代を 基準に乳腺含有染考比較すると，50歳代より若い40歳 代でも，CBTが10mm愿け机ばすべて低值を示し，近 に50歳代より高歯令である60歳以上でも，CBTが10mm 薄ければすべて高值を示すことが認められた。よっ て，乳腺含有率は年齢階級だけで評俩はできず，CBT と…元的に評佂すべきであることが示された。

\section{4. 芦 密}

\section{4-1 乳腺含有率に対する年歯令要因とCBT要因との統 計的影響関係}

Wolfe $\mathrm{e}^{5}$ は，乳腺実質量が加齿によって減少するこ
とを指摘し, Geiseら は，乳腺含有率とCBTとの間に 具の相関関係が認められることを示している。しか し，乳腺含有率に対する年齢とCBTとの影響関係を明 らかにした報告はほとんどみられない，本研究の目的 は，乳腺含有率を推定する関係式を導出し，推定され た乳腺含有率に対する年齢要因とCBT要因との影響関 係を統計的に明らかにするとともに，年齢階級抢よび CBTと乳腺含有率との一般的関係を示古ことにある. 本研穵の厅法で推定された乳腺含有率を多变量解析し た結果，年齢要因とCBT要因は，ともに乳腺含有率と 傎の相関関係にあることが支持され，さらに，年齢要 因よりもCBT要因の力が有意に影響力の大きいことが

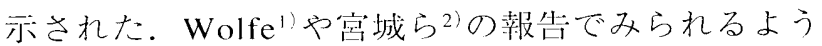
に，乳腺実質量の多さが病変検江能を低下させるとす る議論では，偞齢要因だけが着目される傾问にある。 しかし，本研究では，年齢が若いことよりも， CBTの 溥い小乳房であることの方が，乳腺含有率に対する統 計的な影響力が大きいことを認めた。よって，病変検 出能の低下因子老議論する場合，年歯会要因以上に小乳 房であることの影響を考慮すべきであると指摘でき る。ただし，乳腺実質量が多いことと乳腺含有率が高 いことは，乳腺の分布 ${ }^{3}$ を考慮していない点で同義と はいえない。よって, 病変検出能に及ぼすCBTの影響 
を明確にするには，乳腺含有梁と淀変榆出能との関係 を評侕した研究が必要である。

本研究で乳腺含有率を推定した結果, 20歳代と60歳 以上との乳腺念有率の比率が，CBTによらずほぼ一定 であることを認めた。年歯掯級間で相対化された乳㟫 念有渹の比率を，乳腺含有率の減少率であるとする と, 減少率はCBTに依存しない可能性が示唆される。 したがって，CBT要因との統計的な影響関係を議論す 万場合は，乳腺含有率との直接的な影響関係であるの か，または，脌踰階級間を相刘化した減少率との影響 関係であるのかを，明確に亦すことが必要であるとい える。

本研究は，対象在期間追跡した絴断的研究ではな

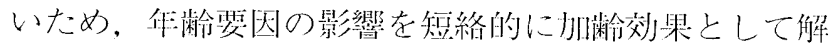

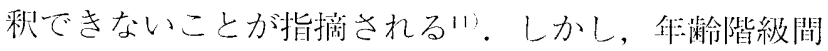
の比較分析は，加速效果の一般的傾问を理解させる意 義があり，この点において本研妴で得た知見は有效な 示唆を与えると考えられる。

\section{4-2 乳腺含有率の統計的推定}

\section{4-2-1 SGC (\%)の推定}

本研究で実施した乳腺含有率の推定に至る過程を要 約すると，1）被検者の年龄階級别にCBTとmAs值との 統計的関係を推測するため，回渌式の繁雑性を考慮し ながら予測精度の最大化を睬る变数操作を行い，2）既 知のSGC (\%) 存有する自作ファントムを使朋し，陻床 での乳房撮影条件と同一に統制したシミュレーション 奏駼から，留齿階級別にSGC (\%)とCBTの関係式を求 め, 3) 乳房撮影被検者が受けた乳腺MRI検相のT強調 横断像から乳腺含有率を算出し, 乳腺含有㳯々SGC (\%)との相関関係寺示与回帰式老求女，4）被検者の年:

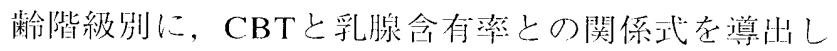
たとなる。

本研究では， $[\ln (m A s) / C B T]$ を往属变数にすると， 回策精度が问上することを認めた。ここで，単色X線 の減弱に関子古直典的公式は, 入射光于数：N, 透過 光于数: $\mathrm{N}_{0}$, 線減弱係数: $\mu$, 吸収体厚 : $\mathrm{x}$ と古る

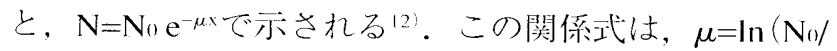
$\mathrm{N}) / \mathrm{x}$ 変形できる。乳房掫影の連繶X線を单色X線と 仮告した場合， $\mathrm{x}=C B T$ から,$\mu=\ln (\mathrm{N} / \mathrm{N}) / C B T$ と近似 される。また，俥乱線の影響を無視すれば，mAs值と X線透過渠との関係は，近似的に傎の線形関係にある

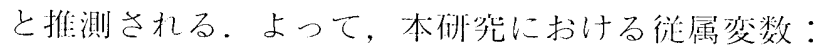
$[\ln (m A s) / C B T]$ は, $\mu=\ln (\mathrm{N} / / \mathrm{N}) / C B T に$ 抢いて, 透過率 の逆数 $(\mathrm{No} / \mathrm{N})$ の代わりに $\mathrm{mAs}$ 值を代朋した变数上い え, 乳房の線減弱倸数に相関する变数であることが指 摘できる。乳厚の線減弱係数は乳原組織の組成に依你 するため ${ }^{13 !},[\ln (m A s) / C B T]$ は乳腺含有率と相関する
変数であることが示睃される。ファントム笑験におい

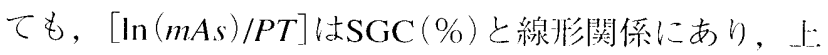
記の示峻を支持するといえる。しかし，独方答数をln $(C B T)$ とすることで，回州精度が向にしたことについ ては，本研穵内で明碓化するに些らなかった。ただ し, SenographeシリーズのAECには，相反則不規の影 響を補匡するアルゴリズムがあり，撮影時間の増㞦に 伴って非線形的にmAs值も增加するように帮御され 万 $^{14)}$. よって，独立变数の刘数变挨が，AECの動作特 性の影響を補正している可能性は指摘できると考えら れる。

対象群に执いて，作萪命階級别に示された $[\ln (m A s) / C B T]$ との統計的な関係をもとに, 乳腺含有 梁を推定するためには，実験的な操作によって，In $(C B T)$ と乳腺含有梁との関係入変擙古万作洋が必琹で ある。本砸究では自作のwater/fatファントムを使腘 し，PT=CBTとすることで， $\mathrm{SGC}(\%)$ を乳腺含有率に 相当する变数とした近似操作を行った。たたし，CBT は压迫国に依存する変数であり，本研觉で示古CBTが $100 \mathrm{~N}$ の压道压による值であったことは明碓にしてお く必要がある。ファントムシミュレーションの結果,

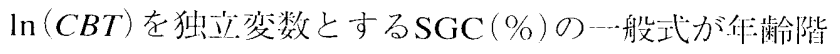
級别に得られた。得られた一般式からSGC(\%)在詶算 した結果, CBTが10mmの場合，すべての隹噛階級で SGC (\%)は100\%を超え, CBTが $20 \mathrm{~mm}$ では20歳代と 30歳代で100\%を超える值を認めた。 SGC(\%)は乳腺 組織を生理食㙉水で，また脂㧍組織をコーンオイルで 近似しているため，この近似操作が掯受妧因になる可 能性は指摘できる。しかし, 乳腺含有率が100\%を超

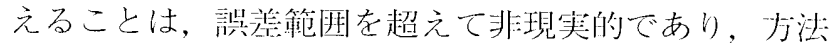
論的な問題が潜在していることを示焌している。本䃤 究では，乳腺分布の不均一性老器視し，AEC受光部で

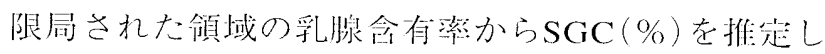
た。これが， $\mathrm{SGC}(\%)$ と現奏の乳腺含有率と老相湋さ せた方法諭にの間題点であると考えられる。よって。 本研穵によるSGC $(\%)$ は，乳腺含有率として稩絡的に 読み換えられないことが示された。

\section{4-2-2 MRIによるSGC(\%)の補正}

本砸穵では，乳腺念有率をMRIの体積测定から求 め, SGC $(\%)$ と乳腺合有渠との相関分析老行い，非え

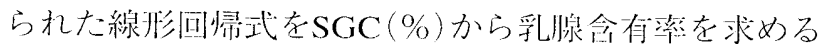
ための補同式として忘用した。ただし，休積測定に利

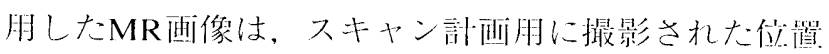
決め画像であり，空聞分解能の点で問題のあることは 指摘して扮かなければならない。補成式は，Y老乳腺 念有染としXをSGC $(\%)$ とした場合， $Y=0.267 X+7.669$ で示された。ここで，MRIによる乳房の脂肪含有率測 定からママンモグラフィに対する主钼的な脂肪会有率 
評価法を再検討したLeeら ${ }^{15)}$ の報告によると, MRIで は脂肪含有率の平均值が66.5\%であるのに対し, マン モグラフィでは42.5\%であったとしている。ただし， Leeらは脂肪含有率に着目しているが，これは排他的 関係として乳腺含有率に読み換え可能である.この相 違についてLeeらは, 三次元構造を有する乳房組織量 を，マンモグラフィで評価する場合，限局的な組織の 重なり, 画像のばらつき, 拡大による歪み, 特性曲線 の非線形性, 圧迫のばらつきが, 評価誤差として問題 になることを指摘している。よって, CR (computed radiography) 画像とBR12ファントムを利用して乳腺含 有率の推定を試みた田中ら ${ }^{16)}$ の研究や, マンモグラフ イから視覚的に乳腺含有率を評価した藤崎ら ${ }^{17)}$ の研究 においても，二次元的な評価である限り，Leeらの指 摘する誤差が潜在していると考えられる。田中らの報 告では乳腺含有率の平均を $36 \%$ とし, 藤崎らの報告で は42.8\%であったとしている. Leeらが求めたMRIに よる脂肪含有率の評価值とマンモグラフィによる評価 值の平均を乳腺含有率に概算し，それらの比 $(33.5 /$ $57.5=0.58)$ を $36 \%$ と $42.8 \%$ に積算すると, それぞれ約 $20.9 \%$ と $24.8 \%$ になる。この值は, 本研究で算出した 50 歳代における $\mathrm{CBT}=40 \mathrm{~mm}$ と $\mathrm{CBT}=30 \mathrm{~mm}$ の乳腺含有 率である $20.6 \%$ と $25.2 \%$ にそれぞれ近い值となる。し たがって, Leeらが指摘するように，二次元画像のマ ンモグラフィをもとに評価した值は, 本研究で算出し たSGC $(\%)$ のように過剩評価となっている可能性が示 唆される。よって，絶対值として乳腺含有率を示すに は，本研究のように，MRIなどを利用した三次元的な 体積測定による補正式が必要であると指摘できる。た
だし，本研究で行ったSGC(\%)の算出方法は，CR画 像や線量測定を必要としないため, 設備上の制限が少 なく，より多くの施設で簡便に応用可能である.さら に，ファントム撮影での管電圧, ターゲット, フィル タの設定を乳房撮影と同一に統制すると，基本的な変 数はmAs值とCBT, および被検者の年齢階級だけにな るため，主観的な視覚評価法に対し，より客観的に大 量のデー夕を統計的に評価できるという利点がある. よって, ファントムシミュレーションで使用するファ ントムの組成や構造を規格化すれば，全国規模で大量 のデータが容易に収集可能となり，乳腺含有率に対す る地域性や生活環境の影響を比較研究できる可能性が 期待できる。

\section{5. 結 語}

本研究では, 乳房撮影被検者の年龄階級, CBTおよ びmAs值をもとに, ファントムシミュレーションと乳 腺MRIのT 強調横断像から, 乳腺含有率を統計的に推 定する関係式を導出した。 また, 乳腺含有率の推定に おいて, 均一構造を有するファントムシミュレーショ ンから求められた值は, 乳腺含有率の相対值としての 意味しかなく, MRIなど三次元的な乳腺実質量の測定 によって補正しなければ過剩評価になる可能性を示唆 した。さらに, 推定された乳腺含有率を従属変数と し, 年齢階級とCBTを要因とした多変量解析から, 年 齢要因抢よびCBT要因が乳腺含有率と負の相関関係に あることを支持するとともに，乳腺含有率に対する統 計的影響は，年齢要因よりもCBT要因の方が有意に大 きいことを示した。 
参考文献

1) Wolfe JN, and Wilie RC: Breast pattern classification and observer error. Radiology, 127, 343-344, (1978).

2) 宮城由美，岩瀬拓士，岩田広治，他：マンモグラフィにお ける乳腺実質量評価の一致率に関する検討。日乳癌検診学 誌, $10(2) ， 179-184$, (2001).

3) (社) 日本医学放射線学会 /(社) 日本放射線技術学会, マン モグラフィガイドライン委員会編：マンモグラフィガイド ライン。医学書院, 東京, (1999).

4) Sobol WT, and Wu X: Parameterization of mammography normalize average glandular dose table. Med Phy, 24 (4), $547-$ $554,(1997)$.

5) Wolfe JN: Breast parenchymal patterns and chanes with age. Radiology, 121, 545-552,(1976).

6) Geise RA, and Palchevsky A: Composition of mammographic phantom materials. Radiology, 198, 347-350, (1996).

7) Sandrik JM: Image quality and dose benefits of the Senographe DMR. GE Medical Systems, Milwaukee, (1994).

8) Stanton L, Villafana T, Day JL, et al.: Dosage evaluation in mammography. Radiology, 150, 577-584, (1984).

9) Sato N, and Ogura T: Evaluation of absorbed dose of the mammary gland with a minute organic detector. Jpn J Radiol Technol, 44 (11), 1583-1591,(1988).

10) 永田 靖, 吉田道弘: 統計的多重比較法の基礎. サイエン ティスト社，東京，(1999）。
11) 古谷野 亘, 長田久雄: 実証研究の手引き一調查と実験の 進め方・まとめ方。ワールドプランニング, 東京, (1997).

12) CurryIII TS, Dowdey JE, and Murry, Jr: Basic interaction between $X$ rays and Matter, Christensen's physics of diagnostic radiology. Fourth Edition, pp.61-69, Lea \& Febiger, Pennsylvania, (1990).

13) Hammerstein G, Miller DW, White DR, et al.: Absorbed radiation dose in mammography. Radiology, 130, 485-491, (1979).

14) Heidsieck R, Gregoire Y, and Bouscary F: Aoutomatic exposure control (AEC) in mammography: A new method based on the determination of equivalent object thickness. General Electoric CGR, DEPN, 283, rue de la Miniere, 78530 BUC, France, (1991).

15) Lee NA, Rusinek H, Weinreb J, et al.: Fatty and fibroglandular tissue volumes in the breasts of women 20-83 years old: Comparison of X-ray mammography and computer-assisted MR imaging. Am J Rentgenol, 168, 501-506, (1997).

16) 田中潡司, 山本 剛, 清本昌義, 他：CR画像を用いた乳腺 含有率および乳腺組織吸収線量の推定. 日放技学誌，56 (7), 921-928, (2000).

17）藤崎達也, 熊谷曜子：圧迫乳房モデルによる乳腺平均吸収 線量の検討. 日乳癌検学誌，6(3)，291-298，(1997).

Fig. 1 シミュレーション用ファントムと乳房撮影装置との幾何学的関係

(a) 配置の側面図

(b) 配置の正面図

Fig. $2 \mathrm{SGC}(\%)$ と乳腺含有率との相関関係。散布図と回㷌式は，全対象のうち，乳腺のMRI検查を受けた57症例に行った相関分 析の結果を示したものである。乳腺含有率はMRでの体積測定によって求められた。 R²は決定係数(R-square)である。

Table 1 対象における年齢階級別の標本統計量

Table 2 各年齢階級に扔ける $\ln (m A s) / C B T$ と $\ln (C B T)$ との関係式. 関係式に扔けるYとXは，それぞれ $\ln (m A s) / C B T$ と $\ln (C B T)$ を表 している.

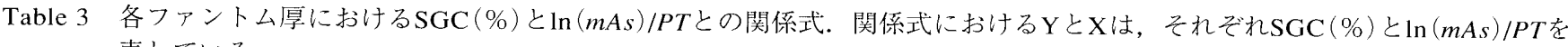
表している.

Table $4 \mathrm{SGC}(\%)$ の推定値と年齢階級別のCBT とSGC $(\%)$ との関係式. 関係式におおけるYとXは，それぞれSGC $(\%)$ とBTを表して いる.

Table 5 乳腺含有率の推定值と年齢皆級別のCBTと乳腺含有率との関係式. 関係式におけるYとXは，それぞれ乳腺含有率とCBTを 表している. 